\title{
Colour and Ammonia Nitrogen Removal from Stabilised Leachate Using Two Stages Coagulation: Tapioca coagulant and Electrocoagulation
}

\author{
N.F. Jamaludin ${ }^{1}$, M.Z.N. Shaylinda ${ }^{1}$, N.A.A. Omar ${ }^{1}$ and S.N.A. Mohd-Salleh ${ }^{1}$ \\ ${ }^{l}$ Faculty of Civil Engineering and Built Environment, Universiti Tun Hussien Onn Malaysia, 86400 Parit Raja, \\ Batu Pahat, Johor, Malaysia \\ *Email: nursha@uthm.edu.my
}

\begin{abstract}
Leachate produced in municipal solid waste landfills is known to have very high concentrations of organic and inorganic pollution substances that could contaminate the surrounding. Degradation of leachate pollutants by coagulation was done conventionally by using single chemical coagulation. The application of natural coagulants, together with electrocoagulation (EC) is still at an uncertain stage. The purpose of this study was to investigate the ability of two stages of coagulation (TSC) consisting of coagulation (tapioca starch coagulant) and EC in removing colour and ammonia nitrogen from stabilising leachate under the influence of dose, leachate $\mathrm{pH}$, duration, and electric current. Coagulation of tapioca starch without EC, removed $24 \%$ and $18 \%$ of colour and ammonia nitrogen, respectively. However, combining EC with coagulation at the optimum duration (20 minutes), a dose of TF $(2.5 \mathrm{~g} / \mathrm{L})$, leachate $\mathrm{pH}(7)$, and electric current $(0.15 \mathrm{~A})$ achieved $37 \%$ and $61 \%$ removal of colour and ammonia nitrogen, respectively. The enhancement of colour and ammonia nitrogen were recorded by TSC. Therefore, TSC is proven able to improve colour and ammonia nitrogen removal from stabilised leachate.
\end{abstract}

Indexed Terms- Natural coagulant, dual coagulation, electricity, landfill leachate, solid waste

\section{INTRODUCTION}

Solid waste generated each day brings a negative impact to the environment if not properly managed. The generation of solid waste is the source of several types of pollution, such as air, soil, and water pollution. It not only affects the environment, but solid waste also can affect social and human health. A mitigation action is important in controlling these pollutions. One of the mitigation aspects that is crucial to be focused on is leachate treatment.

Leachate is the liquid that drains or 'leaches' from a landfill [1]. Leachate may produce in various compositions based on the age of landfill and the type of waste contains [1-2]. Leachate from landfill usually contains extracted, dissolved, and suspended materials, some of which may be harmful [2-3]. The ineffectiveness of leachate management can lead to water pollution to the nearby river or groundwater. Leachate will cause a severe threat to the environment, surrounding soil, and underlying groundwater if the spread of contamination content found in landfill leachate is allowed. The infiltrations of contamination into the soil increase the risk of degradation of human health since groundwater is the major source of drinking water worldwide [4]. Therefore, treatment of leachate is essential.

One of the conventional methods in treating leachate in the primary treatment stage is coagulation. Conventional coagulation is a process of mixing the coagulant with wastewater, which produced floc that is settled by gravity. Most of the coagulant used was chemical coagulant [4]. The natural coagulant is less exploited in this system, as it is not as good as a chemical coagulant and most of the natural coagulant study is just in the laboratory stage [5]. Even though chemical coagulant has a negative effect on the health of people compared to natural coagulant, a chemical coagulant is still widely accepted. 
Another way of coagulating and flocculating pollutants in wastewater is EC. EC is a common process in treating industrial wastewaters because of the versatility and environmental compatibility [67]. Besides having a short reaction retention period, EC processes have no chemical addictive and have a lesser amount of precipitate or sludge, as Jotin et al. [8] concluded in their study. Furthermore, MohdAmdan et al. [6] also found that EC requires no filters, no daily maintenance, and removes any size of suspended solids, oil, grease, and heavy metals.

Based on previous studies [9-13], most of the coagulation treatments were only focusing on separate treatment, whether coagulation, chemical coagulation, or EC. Also, most previous studies only focusing on chemical coagulants instead of natural coagulants. Hence, in this study, TSC (a combination of coagulation (TF coagulant) and EC) was conducted to investigate the ability of this combination technique under the influence of dose of $\mathrm{TF}$, leachate $\mathrm{pH}$, duration, and electric current in removing colour and ammonia nitrogen from stabilised leachate.

\section{MATERIALS AND METHODS}

Leachate sample was collected from Simpang Renggam landfill (1 $\left.{ }^{\circ} 53^{\prime} 41^{\prime N} \mathrm{~N} 103^{\circ} 22^{\prime} 35^{\prime \prime} \mathrm{E}\right)$. This landfill is validated to generate stabilised leachate $[1,14]$. The sampling and preservation of the samples were made according to the Standard Method for the Examination of Water and Wastewater [15].

Coagulation experiments were performed in a conventional jar-test apparatus (VELP-Scientifica, Model: J LT6, Italy). The operating conditions of the jar test were listed in Table 1 . The volume of the leachate sample used in the study was $500 \mathrm{~mL}$. In the jar test of the coagulation process, two varied factors tests were a dose of TF and leachate $\mathrm{pH}$. The $\mathrm{pH}$ of the leachate sample was altered by using $1 \mathrm{~N}$ hydrochloric acid $(\mathrm{HCl})$ and $1 \mathrm{~N}$ sodium hydroxide $(\mathrm{NaOH})$.

After obtaining the optimum $\mathrm{pH}$ and TF dose from the coagulation experiment, the experimental work was continued with the TSC, which consisted of coagulation and EC. The variables considered for the determination of optimum condition for this combined method were duration and electric current following Zailani et al. [14] and Mohd-Amdan et al. [16]. The coagulation process in rapid mixing was conducted as usual while the EC took place in the slow mixing. A pair of iron plates with a dimension of $200 \mathrm{~mm} \times 50 \mathrm{~mm} \times 1 \mathrm{~mm}$ with an effective area of $45 \mathrm{~cm}^{2}$ were dipped into the sample. The spacing between the electrodes is $9.5 \mathrm{~cm}$. The electrode is connected to the electric source using the wire and crocodile clip. The laboratory DC power supply was used to adjust the electric current. Leachate was firstly added with TF and stirred at $200 \mathrm{rpm}$ for 4 minutes to allow the floc to grow large enough for removal without any current flow. Then, the electrodes were connected to the power source to begin the EC process. After the EC process was completed, the sample was allowed to settle for 30 minutes. Supernatant samples were withdrawn and sent for analysis. The removal of colour and ammonia nitrogen were calculated by using Equation 1.

Removal $(\%)=\frac{\text { Initial concentration-Final concentration }}{\text { Initial concentration }} \times 100$

\section{RESULTS AND DISCUSSION}

The optimum dose of TF was determined using different dose values of coagulant between 1.6-3.2 g/L, as shown in Figure 1. The removals have an increment with the addition of TF until $2.5 \mathrm{~g} / \mathrm{L}$ of TF. Beyond $2.5 \mathrm{~g} / \mathrm{L}$, decrement trends were recorded for colour and ammonia nitrogen. Therefore, the optimum dose of TF was $2.5 \mathrm{~g} / \mathrm{L}$. At this optimum dose, removal for colour and ammonia nitrogen were $21 \%$ and $26 \%$, respectively. Shaylinda et al. [10] show better removal of colour and lower removal of ammonia nitrogen compared to this study. Probably, different characteristic of leachate influences the removal ability of TF.

Figure 2 shows the effect of $\mathrm{pH}$ on removing colour and ammonia at a $2.5 \mathrm{~g} / \mathrm{L}$ dose of TF. The values of $\mathrm{pH}$ tested were between 3-8. Based on the removal trends for colour and ammonia nitrogen, better removals were recorded at an alkaline $\mathrm{pH}$ range. At $\mathrm{pH} 8$, the removals of ammonia nitrogen and 
colour had the same percentage removal, i.e., 30\%. However, $\mathrm{pH} 7$ was selected as the fixed leachate $\mathrm{pH}$ for the next experimental work to maintain the natural $\mathrm{pH}$, and the removal of colour and ammonia nitrogen at leachate $\mathrm{pH} 7$ was not significantly different from $\mathrm{pH} 8$.

The effect of EC duration was investigated in the range of 5-25 minutes for the TSC. $2.5 \mathrm{~g} / \mathrm{L}$ dose of TF was mixed with $\mathrm{pH} 7$ of leachate at $200 \mathrm{rpm}$ for 4 minutes. Then, the electric current was supplied at $0.02 \mathrm{~A}$ according to the duration needed. The removals of colour initially increased, then fluctuate as duration increased. However, the best removal of colour was obtained at 20 minutes with $38 \%$ removal. As for ammonia removal, a significant increment was recorded as the EC duration increased (Figure 3). The highest removal was recorded at 25 minutes, with $52 \%$ removal. Nevertheless, 20 minutes of EC is the duration value that satisfied both colour and ammonia nitrogen removals.

The optimum electric current for the TSC was examined by varying the current between 0.020.35A. Different values of electric current were applied for 20 minutes after the completion of TF addition and 4 minutes of rapid mixing. Figure 4 showed that the best electric current flow was $0.15 \mathrm{~A}$. At this optimum electric current, $37 \%$ and $61 \%$ of colour and ammonia nitrogen were removed, respectively. A single electrocoagulation study by Zailani et al. [14] recorded lower removal (37\%) of ammonia from leachate. Thus, based on overall experimental work, TSC exhibits better removal compared to coagulation without EC. The removal of colour increased from $21 \%$ to $37 \%$. A significant improvement was recorded for ammonia nitrogen removal as $61 \%$ removal was recorded by TSC compared to just $26 \%$ recorded by TF coagulation.

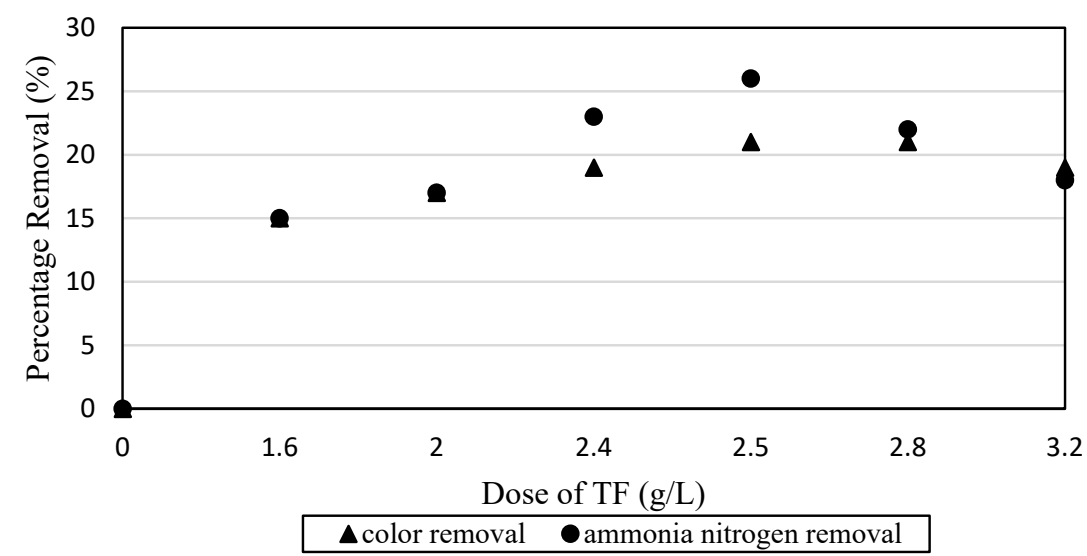

Figure 1: Coagulation under the influence of TF dose

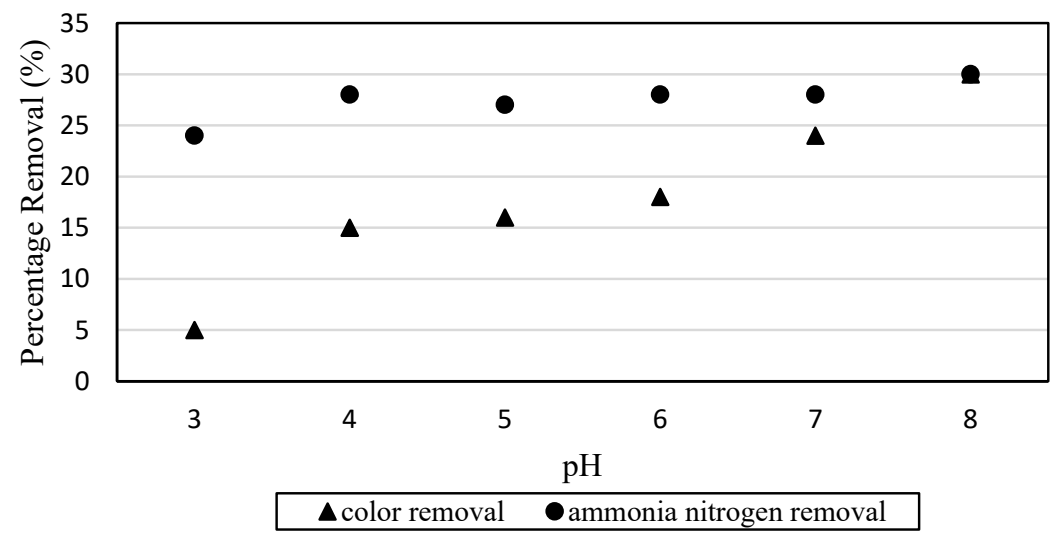

Figure 2: Coagulation under the influence of leachate $\mathrm{pH}$. 


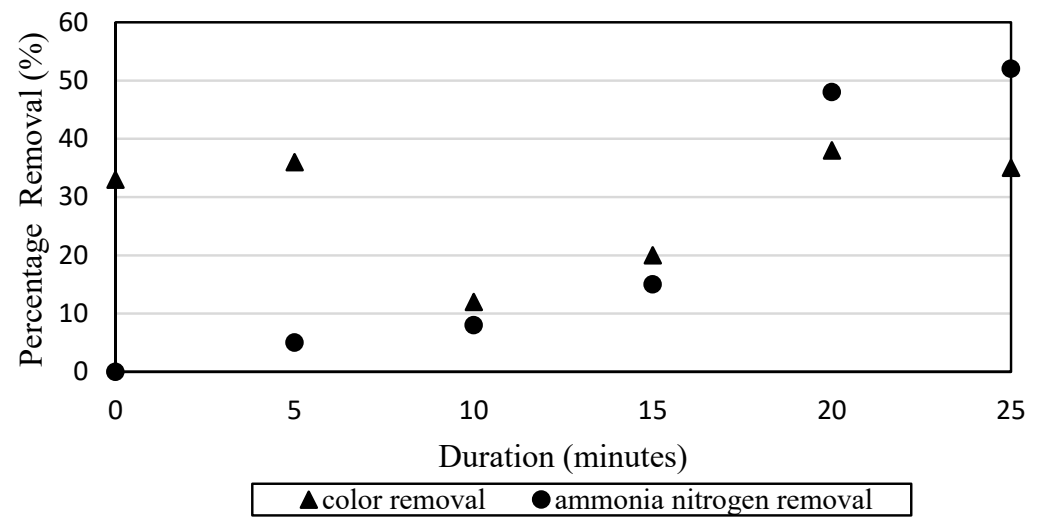

Figure 3: Two stages of coagulation under the influence of duration.

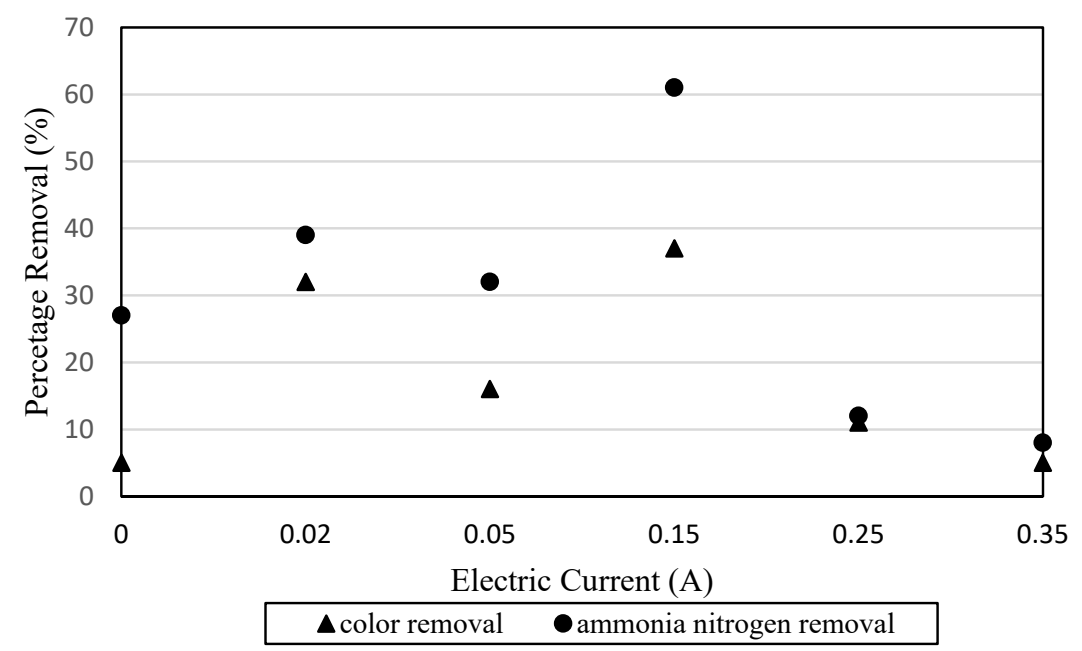

Figure 4: Two stages of coagulation under the influence of current.

\section{CONCLUSIONS}

It could be concluded that leachate $\mathrm{pH} 7,2.5 \mathrm{~g} / \mathrm{L}$ of TF dose, 20 minutes of $\mathrm{EC}$, and $0.15 \mathrm{~A}$ electric current were the optimum values for colour and ammonia nitrogen removal by TSC (coagulation and EC). EC after coagulation significantly improved the removal efficiency, especially for ammonia nitrogen removal. The results of this study suggested that TSC consist of coagulation (TF coagulant), and EC can be a feasible method in removing colour and ammonia nitrogen from stabilised leachate.

\section{Nomenclature:}

$\begin{array}{ll}\mathrm{A} & \text { Ampere } \\ \mathrm{cm} & \text { centimetre } \\ \mathrm{g} / \mathrm{L} & \text { gram per litre } \\ \mathrm{mm} & \text { millimetre } \\ \mathrm{mL} & \text { millilitre } \\ \mathrm{rpm} & \text { revolutions per minute } \\ \% & \text { percentage }\end{array}$




\section{ACKNOWLEDGEMENT}

This research was supported by Universiti Tun Hussien Onn Malaysia (UTHM) through TIER 1 Grant Vot H860.

\section{REFERENCES}

[1] Mohd-Salleh S. N. A. Shaylinda M. Z. N. Othman N, Azizan M. O., Yashni G. Afnizan W. M. W. "Sustainability analysis on landfilling and evaluation of characteristics in landfill leachate: a case study", IOP Conf. Ser. Mater. Sci. Eng., 072002, 2020.

[2] Mohd-Salleh S. N. A. Shaylinda M. Z. N. Othman N. Mohd-Amdan N. S. Mohd-Shahli F. "Dosage and $\mathrm{pH}$ optimization on stabilized landfill leachate via coagulation-flocculation process", MATEC Web Conf., 06007, 2008.

[3] Zainol N. A. Aziz H. A. Yusoff M. S. Umar M. "The use of Polyaluminum Chloride for the treatment of Landfill Leachate via Coagulation and Flocculation processes", Res. J. Chem. Sci., 13, 2011.

[4] Mohd-Salleh S. N. A. Shaylinda M. Z. N. Othman N. Yashni G. Norshila A. B. "Coagulation Performance and Mechanism of a New Coagulant (Polyaluminium Chloride -Tapioca Peel Powder) For Landfill Leachate Treatment”, J. Eng. Sci. Technol., 3709-3722, 2020.

[5] Mohd-Salleh S. N. A. Shaylinda M. Z. N. Othman N. Yashni G. "Optimisation of Tapioca Peel Powder as Natural Coagulant in Removing Chemical Oxygen Demand, Ammonia Nitrogen, Turbidity, Colour, and Suspended Solids from Leachate Sample”, Book Chapter Water Env. Eng., 69-86, 2020.

[6] UN U. T. A. Koparal S. Ogutveren U.B. "Electrocoagulation of vegetable oil refinery wastewater using aluminum electrodes", J. Env. Manage., 428-433, 2009.

[7] Mohd-Amdan, Shaylinda M. Z. N. Mohd-Salleh S. N. A. "Leachate Treatment by Conventional Coagulation, Electrocoagulation and Two-Stage Coagulation (Conventional Coagulation and Electrocoagulation)", Book Chapter Water Env. Eng.,10-22, 2018.

[8] Jotin R. Ibrahim S. Halimoon N. "Electro coagulation for removal of chemical oxygen demand in sanitary landfill leachate", Int. J. Env. Sci., 921-930, 2012.

[9] Renou S. Givaudan J. G. Paulain S. Dirassouyan F. Moulin, P. "Landfill leachate treatment: review and opportunity", J. Hazard. Mater., 468-493, 2008.

[10] Shaylinda M. Z. N. Aziz H. A. Adlan M. N. Ariffin A. Yusoff M. S. Dahlan I. "Treatability Study of Partially Stabilized Leachate by Composite Coagulant (Prehydrolyzed Iron and Tapioca Flour", Int. J. Sci. Res. Knowl., 313-319, 2014.

[11] Fatehah M. O. Hossain S. Teng T.T. "Semiconductor Wastewater Treatment Using Tapioca Starch as a Natural Coagulant", J. Water Res. Prot., 1018-1026, 2013.

[12] Aziz H. A. Daud Z. Adlan, M. N. Hung Y. T. "The use of polyaluminum chloride for removing colour, COD and ammonia from semi-aerobic leachate", Int. J. Environ. Eng., 1, 20-35, 2009.

[13] Ilhan F. Kurt U. Apaydin O. Gonullu M. T. "Treatment of leachate by electrocoagulation using aluminum and iron electrodes", J. Hazard. Mater., 381-389, 2007.

[14] Zailani L. M. Amdan N. M. Shaylinda M. Z. N. "Removal efficiency of electrocoagulation treatment using aluminium electrode for stabilised leachate", IOP Conf. Ser.: Earth Env. Sci., $012049,2018$.

[15] APHA, AWWA and WEF. "Standard Methods for the Examination of Water \& Wastewater, 23rd Edition", Washington DC: American Public Health Association, 2017.

[16] Mohd-Amdan N. S. Shaylinda M. Z. N. Mohd-Salleh S. N. A. Zailani L. W. M. "Addition of composite coagulant (polyaluminium chloride and tapioca flour) into electrocoagulation (aluminium and ferum electrodes) for treatment of stabilized leachate", MATEC Web Conf., 06009, 2018. 